NBER WORKING PAPER SERIES

\title{
DAMAGES AND INJUNCTIONS IN THE \\ PROTECTION OF PROPRIETARY \\ RESEARCH TOOLS
}

\author{
Mark Schankerman \\ Suzanne Scotchmer
}

Working Paper 7086

http://www.nber.org/papers/w7086

\section{NATIONAL BUREAU OF ECONOMIC RESEARCH 1050 Massachusetts Avenue \\ Cambridge, MA 02138 \\ April 1999}

We are grateful to the Sloan Foundation and the National Science Foundation for financial support, and to the managers, scientists, and lawyers in many biotechnology firms who provided valuable information about the biotechnology industry and the legal context in which it operates. We thank Stephen Maurer for guidance on legal issues and many helpful suggestions, and also Rebecca Eisenberg, Brian Wright, and other participants at the NBER conference on the Patent System and Innovation (January 1999) for helpful discussions. The views expressed herein are those of the authors and do not necessarily reflect the views of the National Bureau of Economic Research.

C 1999 by Mark Schankerman and Suzanne Scotchmer. All rights reserved. Short sections of text, not to exceed two paragraphs, may be quoted without explicit permission provided that full credit, including $\mathbb{C}$ notice, is given to the source. 
Damages and Injunctions in the Protection

of Proprietary Research Tools

Mark Schankerman and Suzanne Scotchmer

NBER Working Paper No. 7086

April 1999

JEL No. K0

\section{ABSTRACT}

Profit on proprietary research tools is determined partly by the remedies for infringement, such as damages and injunctions. We investigate how damages under a liability rule and the opportunity for injunctions under a property rule can affect the incentives to develop research tools. We show that the prevailing legal doctrine of damages under liability rule, called lost profit or reasonable royalty, suffers from a logical circularity which leads to an indeterminacy in permissible damages. This can create insufficient incentives to develop research tools. Incentives can be improved either by a property rule with injunctions or by a liability rule under the doctrine of unjust enrichment.

Mark Schankerman

Department of Economics

London School of Economics

Houghton Street

London WC2A $2 \mathrm{AE}$

UK

m.schankerman@lse.ac.uk
Suzanne Scotchmer

University of California

2607 Hearst Ave.

Berkeley, CA 94720-7320

and NBER

scotch@socrates.berkeley.edu 


\section{Introduction}

Intellectual property is usually conceived as protecting commodities in the end-user market. In modern industries such as biotechnology, another type of proprietary invention has become the focus of much controversy and litigation, namely, technologies which have no direct commercial value to end users, but are inputs to developing such commodities. We will refer to such inventions as research tools or enabling technologies. Examples include the Cohen-Boyer patent on the technology for inserting foreign genetic material into bacteria, the Genentech patent on a technology for getting foreign genes to "express", the PCR technology for replicating DNA in test tubes, gene guns, and recent suppression technologies that cause gene sequences to become inactive. Since research tools are not sold to consumers, the traditional analysis of intellectual property does not apply. The profit on research tools comes from licensing and profit-sharing arrangements with firms that want to use the research tools to create other products. Profit-sharing agreements may take the form of licensing contracts, research joint ventures, and mergers. We observe all three types of arrangements in the biotechnology industry.

The value of any intellectual property depends on how easily it can be enforced. The latter depends both on the costs of litigation and on the remedies for infringement. For products sold to consumers, the remedy can be money damages or an injunction to stop selling the infringing product in the market. Infringement of a research tool has another remedy: an injunction against developing the product, rather than against marketing it. In legal parlance, the difference between damages and injunctions is the difference between a liability rule and a property rule.

An economist's instinct is that the threat of damages should be enough to enforce intellectual property rights, and that injunctions are unnecessary. ${ }^{1}$ However, this view

\footnotetext{
${ }^{1}$ In fact there is very little economics literature on injunctions. Lanjouw and Lerner (1996) study how firms can use preliminary injunctions to force favorable settlement terms when litigation costs are asymmetric, and present some supporting evidence. A preliminary injunction stops alleged infringement during the trial, whereas a permanent injunction (which we study in this paper) occurs after infringement is found, and holds for the life of the patent unless the firms contract around it. Aggarwal
} 
was contradicted in several interviews we conducted with patent counsel and CEOs of biotechnology firms, who viewed injunctions as an indispensable tool in protecting their intellectual property. In this paper we investigate whether appropriately chosen damages can obviate the need for injunctions, and whether such damages are consistent with the legal doctrines on which they are based, namely, the currently favored doctrine of lost profit/reasonable royalty and the less used doctrine of unjust enrichment.

Both the right to collect damages and the right to enjoin an infringing research program are constrained by the doctrine of laches. A failure to make a timely effort to stop infringement can nullify the right to recover damages or to enjoin infringement. After an infringement begins, delay is profitable to the patentholder because delay increases the cost that the infringer has sunk when the firms finally negotiate a settlement. Our analysis not only sheds light on how injunctions can improve on damages as a remedy to infringement, but also provides guidance on how much delay should be allowed before the defense of lachés can be invoked.

Our main conclusions are as follows:

- There is a basic circularity of reasoning that afflicts the lost profits/reasonable royalty doctrine of damages. On one hand, prospective damages determine the profitability of licensing, and on the other hand, the profitability of licensing (hence "lost profits" in case of infringement) determine damages. Because of this circularity, a wide range of damage measures are consistent with the doctrine. Low damages, but not damages high enough to deter infringement, are consistent with it.

- Injunctive relief can improve the incentives to develop research tools under "most" interpretations of the lost profit/reasonable royalty rule. However, injunctions are not an improvement if they must be invoked "too soon" (before the infringer has sunk any costs) or "too late" (so that the potential infringer, anticipating an unfavorable settlement after the injunction, will be deterred from infringement).

(1998) discusses how damages interact with litigation costs. 
Injunctive relief cannot improve on damages under the unjust enrichment doctrine of damages.

- Under a liability rule, the unjust enrichment doctrine of damages provides greater incentives for developing research tools than the lost profit/reasonable royalty doctrine.

A unifying theme in these conclusions is that, if the goal is to increase the profitability of the research tool, then remedies for infringement -either damages under a liability rule or injunction and settlement under a property rule - should not be so stringent that infringement would be deterred in the absence of an ex ante license. Infringement of the research tool is profitable to the patentholder because the infringer must either pay high damages ex post (under the liability rule) or is forced into an ex post negotiation when part of his costs have been sunk (under the property rule). If infringement is deterred, then the owner of the research tool must negotiate an ex ante license before any of the development costs have been sunk. The bargaining assumption that underlies these conclusions is that the firms share the whole bargaining stake when they strike the bargain, namely, the value of the product net of the costs that have not been sunk. ${ }^{2}$

In Section 2 we present a stylized model in which a firm (firm 1) has developed a proprietary research tool, which is an input for second-generation products. Either firm 1 or another firm (firm 2) can develop a product with commercial value using the research tool, but the development process is itself an infringement. Section 2 investigates the liability rule, where the only remedy for infringement is damages. In Section 3 we discuss the legal doctrines of damages that apply in the U.S., and examine which doctrine creates greater incentives for developing research tools. Section 4 analyzes a property rule, where the firms can seek injunctive relief. We also discuss the doctrine of laches, and how it constrains strategic timing of injunctions. In Section 5 we show how the model is modified if there are nonproprietary alternatives to the research tool.

\footnotetext{
${ }^{2}$ Even with several prospective developers, the patentholder cannot collect all the profit by auctioning use of the research tool, provided the second product is itself patentable. See Scotchmer (1996).
} 
Our model has the cumulative features of Scotchmer (1991), and Green and Scotchmer (1995), but we focus on different issues. They investigated the division of profit between sequential innovators, where the second innovation might or might not infringe the first patent, and discussed how patent breadth (the probability of infringement) affects the terms of licensing. For research tools, any unauthorized use of the proprietary tool is an infringement. The division of profit is mainly governed by the remedies for infringement, in particular, the legal theory of damages and the possibility of injunction.

The perspective taken here is that intellectual property rights are not exercised as the right to exclude, but as the right to collect licensing fees by threatening to exclude (under a property rule) or by threatening to collect damages (under a liability rule). Provided the owner of the research tool can collect licensing fees, he can profit by encouraging other firms to use the tool in developing products. The rules for enforcing intellectual property rights set the threat points for licensing agreements, and hence the division of profits. With frictionless licensing, intellectual property will not stifle the development of second-generation products.

This is a different perspective than is often taken by legal scholars such as Eisenberg (1989), and Heller and Eisenberg (1998), who are less optimistic about contracting, and want to ensure that inventions are put to good use even when contracting fails. Injunctions can foreclose the use of research tools when licensing fails, and for this reason Eisenberg argues against giving patent holders injunctive relief for research tools. Instead she proposes that courts impose damages equal to reasonable royalty payments. ${ }^{3}$ Merges (1996) takes a different position, arguing that to exclude injunctive relief and to rely exclusively on damage remedies would put an unmanageable burden on the courts to set damages or compulsory licensing fees in a way that serves the public interest. This

\footnotetext{
${ }^{3}$ She discusses the relative merits of property and liability rules in the context of the experimental use exception in patent law. It remains unclear how broadly U.S. courts will grant this exception. In Roche Products, Inc. v. Bolar Pharmaceuticals Co. 733 F.2d 858 (1983), the Federal Circuit ruled that the experimental use exception did not protect the use by generic drug manufacturers of a patented drug for testing to meet FDA drug approval requirements. This was overruled through legislation by Congress in 1984 (see 35 U.S.Code Section $271(\mathrm{e})(1)$ ). The scope of exempt subject matter under Section $271(\mathrm{e})$ has been extended to cover medical devices (Eli Lilly \& Co. v. Medtronic, Inc. 872 F2d 402,1989 ). European countries and Japan also have experimental use exceptions.
} 
problem can be avoided by permitting injunctions. We also argue that a property rule can be superior to a liability rule, but for a different reason. Since damages consistent with the prevailing doctrine can be too low, the threat of injunction can improve the first patentholder's bargaining position, and improve the incentive to develop research tools.

\section{Analysis of the Liability Rule (Damages)}

We first describe the model, and then analyze how damages affect the research tool owner's profit under a liability rule. In Section 3 we discuss what damages are consistent with legal doctrines.

We assume there are two firms, $i=1,2$, and that a research tool has been patented by firm 1. Either firm can develop a particular product using this tool, and the firms' R\&D costs are respectively $c_{1}, c_{2}$, observable to both firms. The profit available by achieving the product is $v$. We assume throughout that $\min \left\{c_{1}, c_{2}\right\}<v$, so that the firms will want to invest. We assume that unauthorized use of the research tool is an infringement, and that if development of a product was not authorized by a license, then marketing the product is also an infringement.

The premise of our analysis is that it is desirable to transfer the entire profit surplus of the product to the owner of the research tool, where the profit surplus is $\max \{v-$ $\left.c_{1}, v-c_{2}\right\}$. Once the research tool is invented, it is in the interest of the owner not to jeopardize its use in creating new products. The owner will license on terms that the users will accept, since it is better to license at a low price than not to license at all. This places a natural constraint on how much profit can be collected from users of the research tool (it cannot be larger than the profit surplus), and ensures that the tool is used to develop all new products whose profit surplus is nonnegative. For the research tool itself, there is no guarantee that the inventor's costs will be covered, and that is why it is desirable to maximize his profit, subject to the self-imposed constraint that the second generation products are not jeopardized. 
The order of decisions is shown in Figures 1 and 2 for two cases: first, that firm 1 has a pure research tool and no expertise (or very high $\operatorname{costs} c_{1}$ ) to develop the product, and second, that the owner of the research tool might compete with firm 2 in development of the product, or even preempt firm 2 entirely. ${ }^{4}$ Development of the product by firm 2 is an infringement of the research tool, and the firms must either license ex ante or resolve the infringement issue ex post, after the product has been developed. The prospect of resolving the infringement ex post sets the bargaining positions for the ex ante agreement. The considerations relevant to equilibrium profit in both cases are summarized in Table 1.

We assume that in equilibrium the firms will bargain ex ante to an efficient outcome. This means that the product will be developed if and only if it adds to joint profit, and that the most efficient (lowest cost) firm will invest. In addition, an inefficient patent race will be avoided. The role of damages (and other aspects of intellectual property) is that damages determine the threat points for the firms' ex ante bargain. For example, the prospective damages determine whether an unlicensed firm has an incentive to race and then pay damages if it wins. The attractiveness of racing without a license will determine the terms of the license.

Throughout the analysis, we assume that whenever firms make a bargain, they share the bargaining surplus in shares $(\lambda, 1-\lambda)$. To determine the firm's equilibrium profit, the bargaining share is added to the firm's threat point. If the firms have symmetric bargaining positions, then it is natural to assume $\lambda=1 / 2$, as in the Nash bargaining solution. The threat points, bargaining surplus and equilibrium profits are listed in Table 1 for the cases summarized in Figures 1 and 2.

\footnotetext{
${ }^{4}$ According to our interviews, vertical integration of life sciences firms and plant biology firms is increasing. In addition, some biotechnology products naturally play a dual role as research tool and product, e.g., the genetic sequence for a hepatitus $\mathrm{C}$ inhibitor, which is both the basis for a diagnostic product, and a research tool for developing a vaccine.
} 
FIGURE 1. SEQUENCE OF DECISIONS UNDER A LIABILITY RULE FIRM 1 IS A PURE RESEARCH FIRM

Payoffs:

Terms of License

if $d>v-c_{2}$ then $\left(\lambda\left(v-c_{2}\right),(1-\lambda)\left(v-c_{2}\right)\right)$

if $d \leq v-c_{2}$ then $\left(d, v-c_{2}-d\right)$

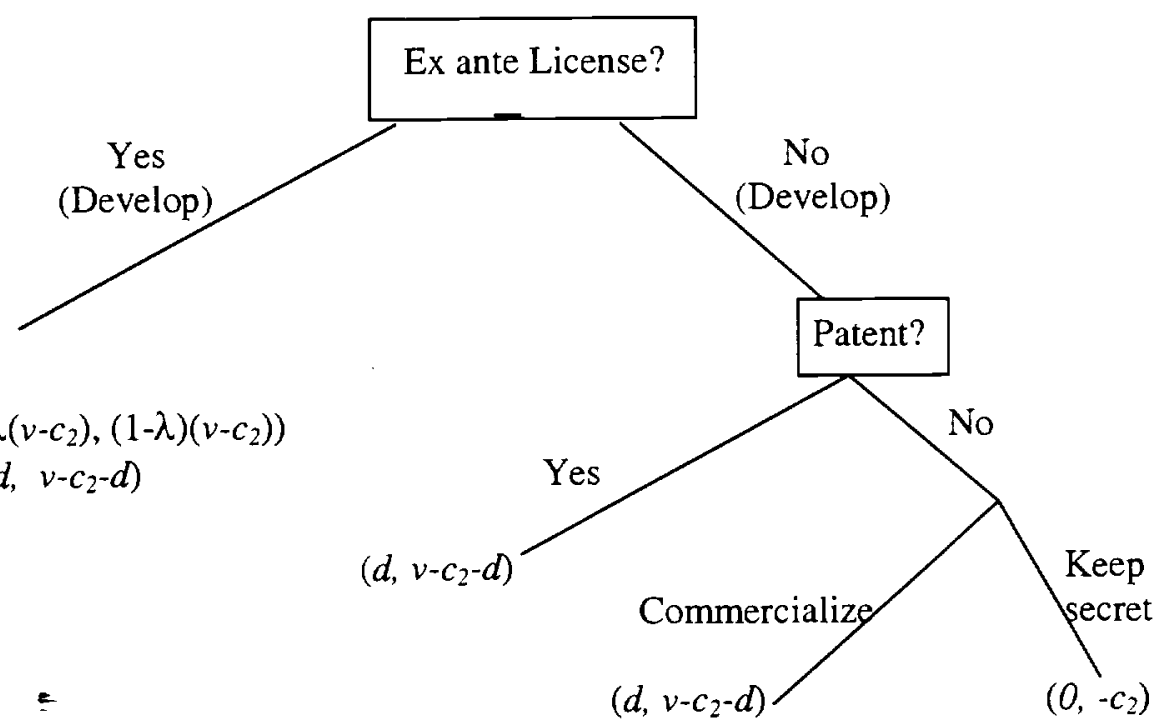

FIGURE 2. SEQUENCE OF DECISIONS UNDER A LIABILITY RULE FIRM 1 CAN DEVELOP THE SECOND PRODUCT

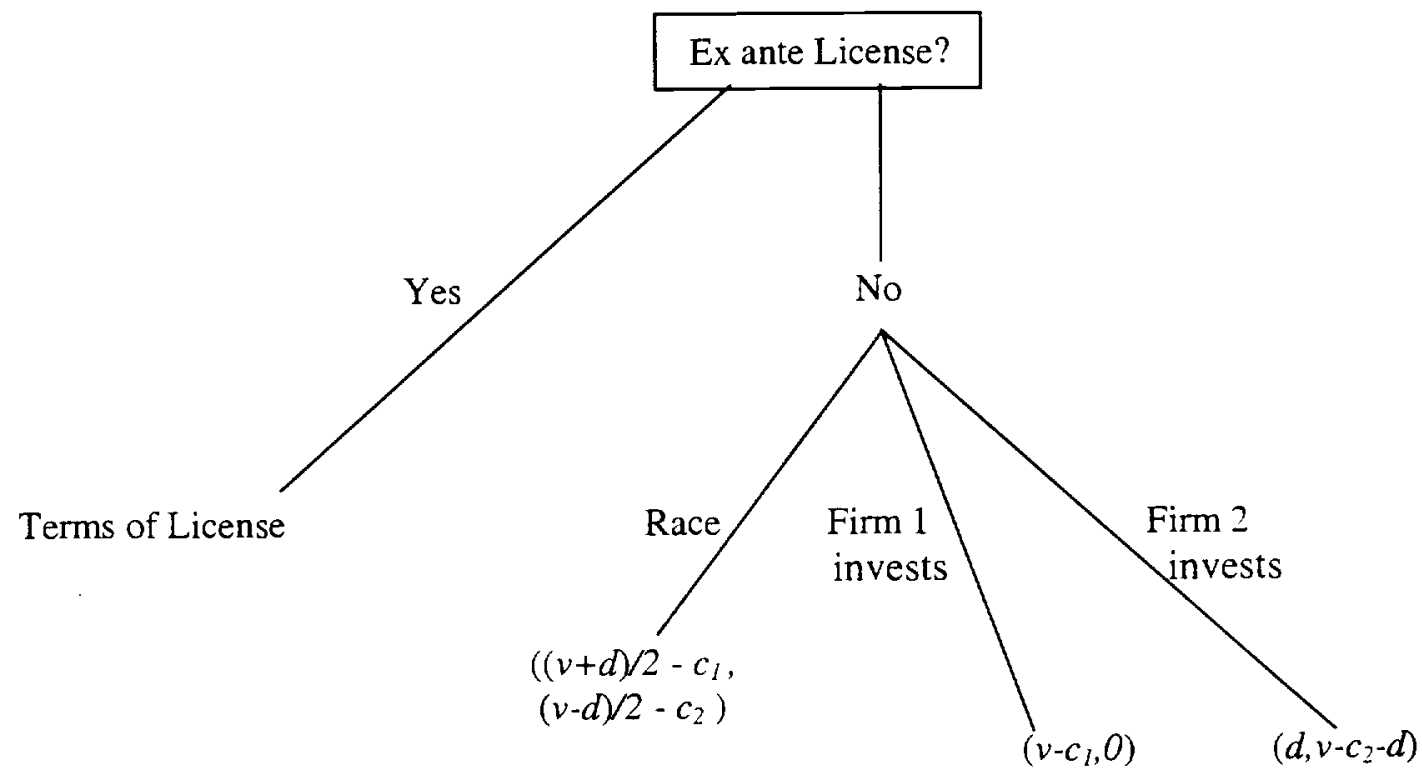




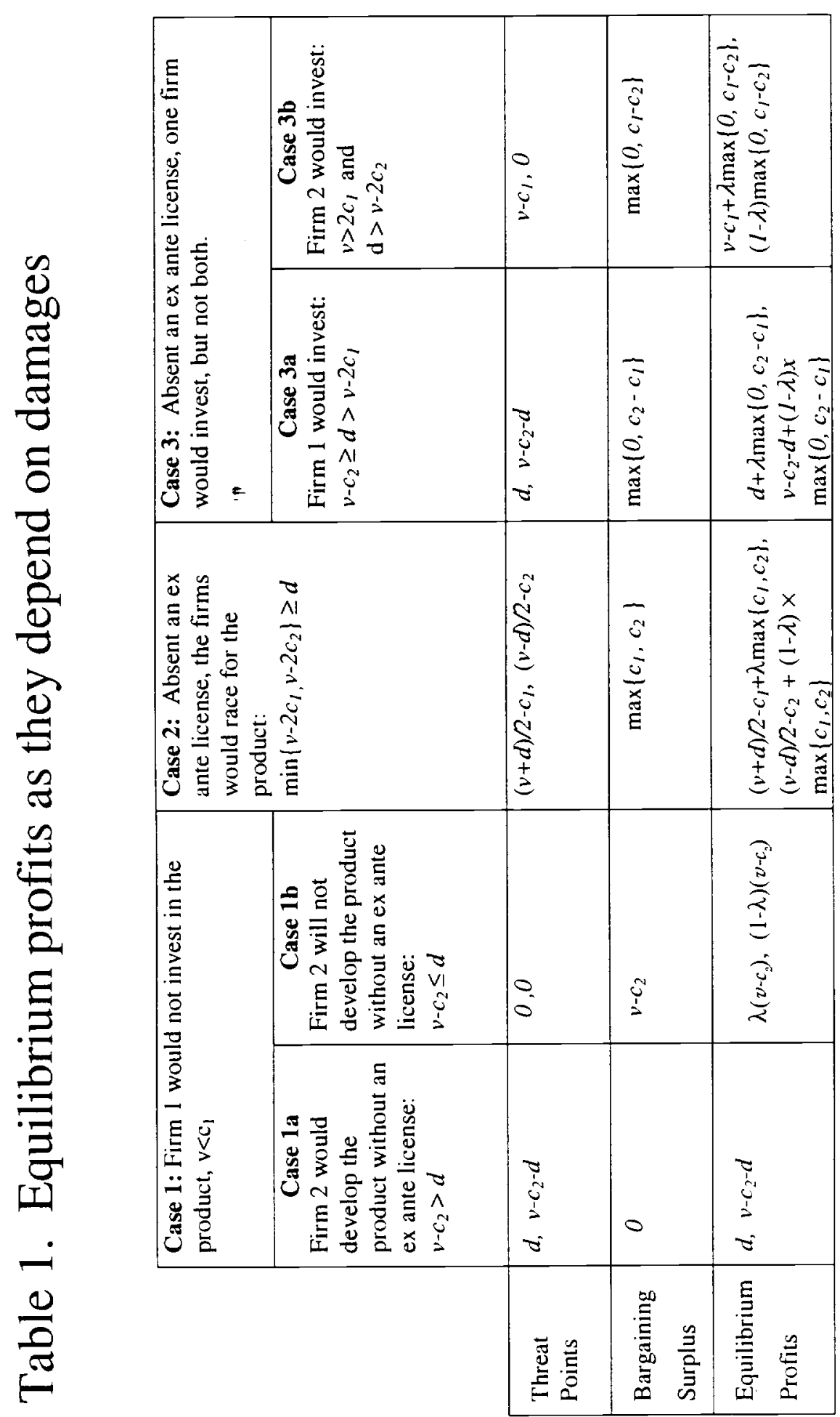




\subsection{Pure Research Tools}

In Cases $1 \mathrm{a}$ and $1 \mathrm{~b}$, described by Figure 1, we assume that $c_{1}$ is very high $\left(c_{1}>v\right)$, so that firm 1 would not invest in the product even if firm 2 failed to invest. Instead he will license to firm $2 .^{5}$ In Case $1 \mathrm{a}$, damages $d$ are relatively small - small enough so that firm 2 would make non-negative profit even if it were caught infringing and paid damages. In Case 1b, damages $d$ are assumed large enough so that firm 2 will not invest . without an ex ante agreement.

Either firm can refuse an ex ante license. Refusal of either firm leads the two of them down the right branch of Figure 1. If firm 2 then invests without an ex ante license, knowing that its research (hence product) will infringe, firm 2 will be charged the damages $d$ if it patents or commercializes the product. Patenting or commercialization involves disclosure, and the infringement is thus revealed.

For completeness, in the rightmost branch after "patent?", we investigate whether firm 2 can avoid these damages by threatening to keep the invention secret in order to enhance its ex post bargaining position. If firm 2 tried to license ex post for smaller license fees than $d$, firm 1 would refuse the ex post settlement, knowing that it is more profitable for firm 2 to commercialize and pay damages $d$ (provided $v-c_{2}-d>0$ ) than to carry out the threat of keeping the invention secret.

Thus, the profits that accrue without an ex ante license are $\left(d, v-c_{2}-d\right)$, and these "threat points" are also the equilibrium profits with an ex ante agreement when damages $d$ are relatively small because there is no further efficiency gain to be shared. This is shown in Table 1, Case 1a.

However if damages for infringement are relatively high, specifically, if $v-c_{2}-d<0$, then firm 2 would end up with negative profit, absent an ex ante agreement. The

\footnotetext{
${ }^{5}$ According to our interviews, owners of research tools often license them for uses that do not overlap with their own downstream business interests. We interpret this as cases where $c_{1}>v$ or $c_{1}>c_{2}$. Because valuation of enabling technologies is difficult, licensing arrangements often take the form of equity stakes rather than cash or royalties. This distinction is not relevant in our models.
} 
righthand branch will not be followed, and an ex ante agreement is necessary to elicit investment. The efficiency surplus to be shared in the ex ante agreement is $v-c_{2}$, which leads to the equilibrium profits $\left(\lambda\left(v-c_{2}\right),(1-\lambda)\left(v-c_{2}\right)\right)$ shown in Table 1, Case 1b.

We reach the following conclusions.

Lemma 2.1. Suppose that firm 1 has a patented research tool which is required to develop a new product with value $v$, and $c_{1}>v>c_{2}$.

Under a liability rule, if $d \leq v-c_{2}$, then equilibrium profits are $\left(d, v-c_{2}-d\right)$.

If $d>v-c_{2}$, then equilibrium profits are $\left(\lambda\left(v-c_{2}\right),(1-\lambda)\left(v-c_{2}\right)\right)$.

The proposition states how damages $d$ should be set in order to maximize the incentive to develop the research tool. As mentioned above, a consequence of efficient ex ante agreements is that thigh prospective damages $d$ will not stifle use of the research tool. A new product will be developed if and only if $v-c_{2}>0$, irrespective of damages for infringement. The only role played by $d$ is in dividing the profit between the firms.

Proposition 2.2. Suppose that firm 1 has a patented research tool which is required to develop a new product with value $v$, and $c_{1}>v>c_{2}$. Under a liability rule, the damages $d$ that lead to maximum profit for firm 1 are $d=v-c_{2}$. Higher damages reduce firm I's profit.

\subsection{Vertically Integrated Firms}

Cases 2 and 3 in Table 1 describe the circumstance where the first patent holder not only owns the proprietary research tool, but also has expertise to develop the downstream product. The different cases in Table 1 reflect different combinations of $\left\{v, c_{1}, c_{2}, d\right\}$. Even if firm 1 has expertise to develop the product $\left(v>c_{1}\right)$, it prefers to delegate to firm 2 if firm 2 is more efficient $\left(c_{1}>c_{2}\right)$. Whether or not firm 1 wants to delegate, firm 2 has the option to infringe the patent and force an ex post settlement in which firm 2 
pays damages $d$ to firm 1. If damages $d$ are relatively low, this threat constrains firm 1 's ability to profit from its research tool.

The bargaining surpluses in Table 1 are derived from three sources: by ensuring that the product is invented when otherwise it would not be (Case 1b); by allowing the firms to avoid the cost-duplication of a patent race (Case 2); and by allowing the firms to delegate research effort to the lowest-cost firm (Cases $3 \mathrm{a}$ and $3 \mathrm{~b}$ ).

Since threat points for the ex ante agreement are set by reference to what would happen otherwise, we must know what would happen in a patent race. A race will never happen in equilibrium, because it duplicates costs. However, the prospect of an inefficient race sets the firms' threat points for the license in Case 2. We assume that if the firms race, each wins with probability one-half. If firm 2 is the winner, then it pays damages $d$ to firm 1 in an ex post settlement of the infringement. Thus firm 2 will race if its expected profit, $(v-d) / 2-c_{2}$, is greater than zero, and firm 1 will race if its expected profit, $(\dot{v}+d) / 2-c_{1}$, is greater than its payoff for not racing, which is $d$. Thus the firms will race if $v-2 c_{1}>d$ and $v-2 c_{2}>d$, shown in Table 1 .

A complication arises when the "race" has room for only one firm. Suppose that either firm can make profit alone $\left(v>c_{1}\right.$ and $\left.v_{2}-c_{2}>d\right)$, but neither can make positive profit if they race. There can be two equilibria, one in which the low-cost firm invests and another in which the high-cost firm invests. The ex ante agreement depends on the firms' joint conjecture about who would invest, absent an ex ante license. If the efficient firm would invest, there is no bargaining surplus to be shared. If the inefficient firm would invest, then the surplus to be shared ex ante is the saved cost, e.g., $c_{2}-c_{1}$ if firm 2 is the inefficient firm.

The equilibrium profits of firm 1 derived in Table 1 are summarized in Figures 3 and 4. Figure 3 depicts the cases where the low-cost firm would invest, absent an ex ante agreement (the low-cost firm can either be firm 1 or firm 2). Figure 4 depicts the cases where the high-cost firm would invest. There are two striking features of Figures 3 and 4. First, firm 1's profit is never monotonic in damages $d$. It drops discontinuously at values 
FIGURE 3. FIRM l's EQUILIBRIUM PROFIT AS IT DEPENDS ON DAMAGES Assume the low-cost firm would invest, absent an ex ante agreement

Case: $c_{1}>c_{2}$

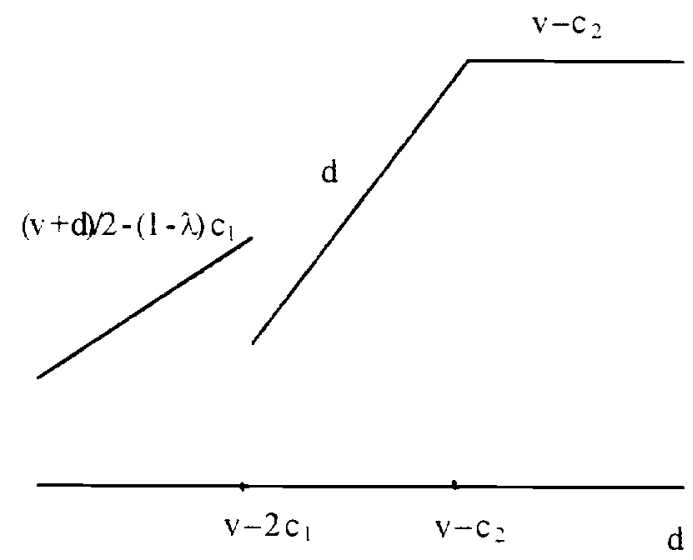

Case: $c_{2}>c_{1}$

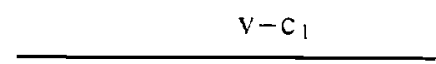

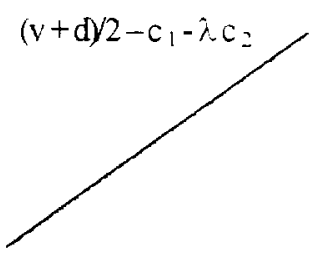

$v-2 c_{2}$

FIGURE 4. FIRM l's EQUILIBRIUM PROFIT AS IT DEPENDS ON DAMAGES

Assume the high-cost firm would invest, absent an ex ante agreement

Case: $c_{2}>c_{1}$

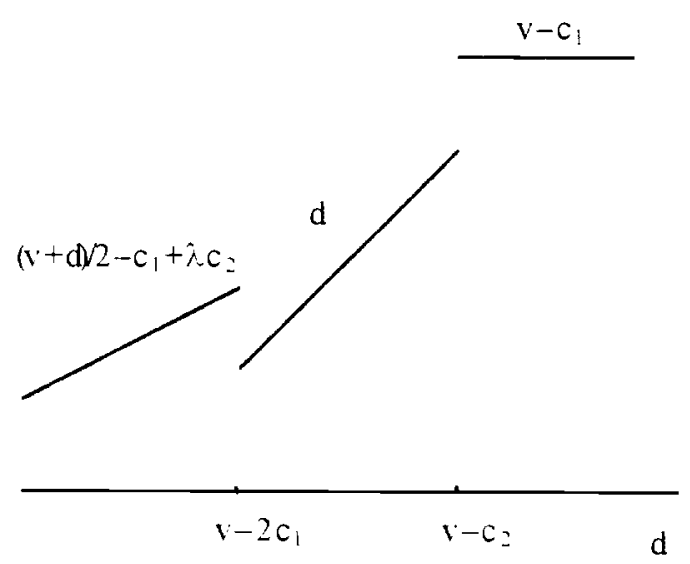

Case: $c_{1}>c_{2}$

$v-c_{1}+\lambda\left(c_{1}-c_{2}\right)$
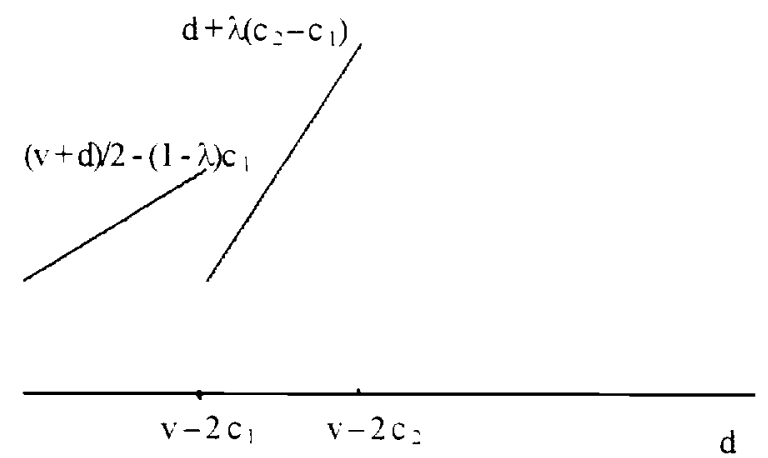
of $d$ where damages have become so large that one of the firms would no longer race. Second, there is no guarantee that damages will allow appropriation of the full surplus by firm 1. The next section shows how appropriation depends on the legal doctrine of damages.

We summarize the important parts of Table 1 and Figures 3 and 4 as:

Proposition 2.3. Suppose that firms 1 and 2 can respectively develop the product at costs $c_{1}$ and $c_{2}$, both smaller than $v$.

(i) Suppose that damages under a liability rule satisfy $d<\min \left\{v-2 c_{1}, v-2 c_{2}\right\}$, so that the firms would race, absent an ex ante license. Then less than the full profit surplus is transferred to firm 1 in an ex ante agreement.

(ii) Suppose that, absent an ex ante agreement, the higher-cost (inefficient) firm would invest in thè product. Then under a liability rule, even if the firms form an ex ante agreement, there is no damage $d$ that results in firm 1 collecting the full profit surplus.

(iii) Suppose that, absent an ex ante agreement, the lower-cost (efficient) firm would invest in the product. Then by setting $d=\min \left\{v-c_{1}, v-c_{2}\right\}$ (damages under a liability rule are equal to the full profit surplus), all the profit is transferred to firm 1.

Proof. (i) Firm 2's equilibrium profit is its threat point, $(v+d) / 2-c_{1}$, plus its bargaining share of the cost saving, $(1-\lambda) \max \left\{c_{1}, c_{2}\right\}$. Both are positive, so firm 2 makes positive equilibrium profit. Since the profit of firm 1 and firm 2 sum to the profit surplus, $\max \left\{v-c_{1}, v-c_{2}\right\}$, it follows that firm 1 does not collect the full surplus.

(ii) Whether the inefficient firm is firm 1 or firm 2, there is a positive bargaining surplus to divide in the ex ante agreement, namely, $\max \left\{c_{1}-c_{2}, c_{2}-c_{1}\right\}$. Hence firm 2 earns positive profit, and as in (i), not all the surplus is transferred to firm 1.

(iii) If firm 1 is the more efficient firm, then $v-c_{1}=d>v-c_{2}$, so firm 2 plays no 
role. Firm 1 invests and receives the surplus. If firm 2 is the more efficient firm, then $d=v-c_{2}$, and all the surplus is transferred to firm 1 as a damage settlement, if not as an ex ante license.

Proposition 2.3 shows that it may not be possible for the developer of the research tool to appropriate the full surplus through the use of only one instrument, damages, even when firms strike ex ante licenses in the shadow of such damages. In the next section we discuss whether full appropriation by the research tool owner is consistent with the prevailing legal doctrines. We then consider whether full appropriation can be achieved with another instrument, injunctive relief.

\section{Legal Doctrines of Damages under the Liability Rule}

In this section we discuss the legal doctrines of damages for patent infringement in the United States, and interpret them for our model. We identify a basic logical circularity in the prevailing legal doctrine of damages, and argue that this circularity reduces the efficacy of damages in enforcing intellectual property rights for research tools. We analyze the case where the tool owner earns revenue only by licensing to other firms (Case 1 in Table 1). The same issue arises in the other cases of Table 1 as well, but the analysis is more complicated.

There is a basic tension that runs through the case law on patent infringement damages. It arises from the fact that there are two different objectives: to deny to the infringer the fruits of his illegal act, and to restore to the patentee the benefits which he would have derived in the absence of infringement (England v. Deere \& Co., $221 \mathrm{~F}$. Supp. 319, 1963). The legal doctrines of damages corresponding to these two objectives are unjust enrichment, and lost profit/reasonable royalty (hereafter, reasonable royalty). The content of these doctrines has evolved over time, but the basic distinction remains. Prior to 1946, when the current statutory rules on damages took form, the courts appear to have given greater weight to unjust enrichment. During the post-war period the courts have relied exclusively on the reasonable royalty doctrine. In that doctrine, the sole basis 
for recovery is the patentee's damages and not the infringer's profits, though the latter may be relevant evidence for computing the patentee's actual damages or a reasonable royalty (e.g., Zegers v. Zegers, Inc. 458 F.2d 726, 1972).

Unjust Enrichment: Under this doctrine, the patent owner is entitled to recover profits realized by the infringer on the theory that the infringer should not profit from his wrongdoing. The infringer is viewed as holding these profits "in constructive trust" for the infringed party. This doctrine was prominent in the late part of the 19th century, and used as late as the second world war (Littlefield v Perry, N.Y. 1875, 188 US 205; Amusement Corp. of America v Mattson, C.C.A. Fla. 1943, 138 F.2d 693). In most case law, the measure of unjust enrichment was the profits realized by the infringer (e.g., Leman v. Krentler-Arnold Hinge Last Co., 284 U.S. 448, 1932). However a number of cases enunciated the more subtle principle that the measure of unjust enrichment should be the advantage gained by using the infringed invention instead of other available, nonproprietary alternatives. ${ }^{6}$

In our model so far, where an infringer could not have developed the product without the patented research tool, the unjust enrichment is $v-c_{2}$. In Section 5 we reinterpret the concept of unjust enrichment for the case where a nonproprietary substitute is available.

Lost Profit and Reasonable Royalty Under this doctrine, damages should restore the patentee to the condition that would have prevailed had the infringement not occurred. This shifts the focus from the infringer's profits to the patentee's foregone profits (Yale Lock Mfg. Co. v Sargent, 117 U.S. 536, 1886). The doctrine as currently applied was enuncicated in Panduit Corp. v Stahlin Bros Fibre Works (575 F.2d 1152, 1978). The court stated that the patentee is entitled to recover "actual damages" (also referred to as "lost profit") or, when these cannot be proved, not less than a "reasonable royalty." The principle is to restore the patentee to the position "but for" the infringement. Whether lost profit is lost sales or lost licensing revenues depends on whether the owner would have developed the application himself or would have licensed to another firm. From an

\footnotetext{
${ }^{6}$ For example, Mowry v Whitney. 81 U.S. 620, 1872; Horvath v McCord Radiator and Mfg. Co., 100 F.2d 326, 1938; Gordon Form Lathe Co. v Ford Motor Co., C.C.A. Mich., 133 F.2d 487, 1943.
} 
evidentiary point of view, this distinction would be hard for courts to assess. ${ }^{7}$ However, in the case we analyze, where the research tool only earns profit through licensing, lost profit is lost licensing revenues. Hence it is the reasonable royalty measure of damages that applies.

Not surprisingly, despite judicial efforts to identify the relevant considerations in setting a reasonable royalty (e.g., Georgia-Pacific Corp. v. United States Plywood Corp., 38 F. Supp. 1116, 1970), the doctrine has proved difficult to implement in a consistent and predictable manner (Conley, 1987). In this paper we make a stronger criticism: the doctrine involves a circularity, with the consequence that a whole range of damage measures $d$ is logically consistent with it. Under the doctrine, damages $d$ can be very low, and licensing in the shadow of such damages might provide only weak incentives for developing research tools.

To see the circularity, recall that foregone profits are foregone licensing revenues. Our earlier analysis shows that firm 1's equilibrium profits are determined by the damages $d$. Firm 1's equilibrium profit (hence its "lost profit" in the case of infringement) is precisely $d$ in the right branch of the tree in Figure 1, where $d$ can have any value less than or equal to $v-c_{2}$. On the other hand, the reasonable royalty doctrine is not consistent with $d>v-c_{2}$ because such damages would force an ex ante license in which the owner of the research tool takes profit $\lambda\left(v-c_{2}\right)$, which is smaller that the putative damages $d$, a contradiction.

We thus have the following observations about legal doctrines of damages:

Remark 1. Damages $d$ are consistent with the reasonable royalty doctrine if and only if $0 \leq d \leq v-c_{2}$. Thus, damages large enough to dissuade infringement, absent an ex ante license $\left(d>v-c_{2}\right)$, are not consistent with this rule. The only damages $d$ that are consistent with the unjust enrichment doctrine are $d=v-c_{2}$.

\footnotetext{
${ }^{7}$ Panduit addressed the evidentiary problem by requiring the patent owner to establish four things in order to recover the profit on lost sales: a demand for the patented product, that there were no acceptable noninfringing substitutes, a manufacturing and marketing capability to supply the market, and the profit that would have been made on lost sales.
} 
Remark 2. The unjust enrichment doctrine transfers the full surplus to the research tool owner. The reasonable royalty doctrine will not transfer the full surplus, except at the maximum damages $d$ consistent with the doctrine.

\section{Analysis of the Property Rule (Injunctions)}

According to interviews with patent attorneys and in-house counsel in biotechnology firms, injunctions are an important instrument to enforce intellectual property rights on research tools. Those interviewed claimed that damages would be less effective without the threat of injunctions. Injunctions encourage ex ante licensing and force ex post settlements when infringement occurs. Moreover, the interviewees recognized that the timing of injunctions affects profits. Delays in requesting injunctions can shift profits to the owner of the research tool, since delay means that the infringer has sunk some of its cost by the time settlement occurs. However, they emphasized that discretion over strategic delay in seeking injunctions is severely limited by the doctrines of laches and estoppel. ${ }^{8}$

We now examine how injunctions can be used to protect intellectual property on research tools. In the previous section we assumed that if no ex ante license is negotiated, the patentholder's remedies are (i) to develop the product, perhaps inefficiently, (ii) to allow infringement by the second firm and collect damages ex post, or (iii) to engage in a (perhaps inefficient) patent race, followed by a damage payment if the second firm wins. We now assume that the patentholder can allow an infringing research program to begin, and then sue for an injunction. The bargaining positions for settlement after injunction are different than they would be for an ex ante license, before any research costs are

\footnotetext{
${ }^{8}$ We found two cases of apparently successful strategic delay in seeking injunctive relief. The first involved Monsanto's Roundup-Ready corn which infringed an enabling technology developed by DNA Plant (DNAP) Technology Corporation (transwitch, a transgenic method for silencing gene expression in plants). DNAP sought an injunction after most of Monsanto's development costs had been sunk, and this led to an ex post license arrangement favorable to DNAP. In the second example. Monsanto obtained a late injunction in 1996 against DNAP for infringing one of its enabling technologies. According to the research director at DNAP, the injunction covered many of its newly developed plant products and led to shutting down the company, which was subsequently bought by Monsanto.
} 
FIGURE 5. SEQUENCE OF DECISIONS UNDER A PROPERTY RULE (INJUNCTIONS)

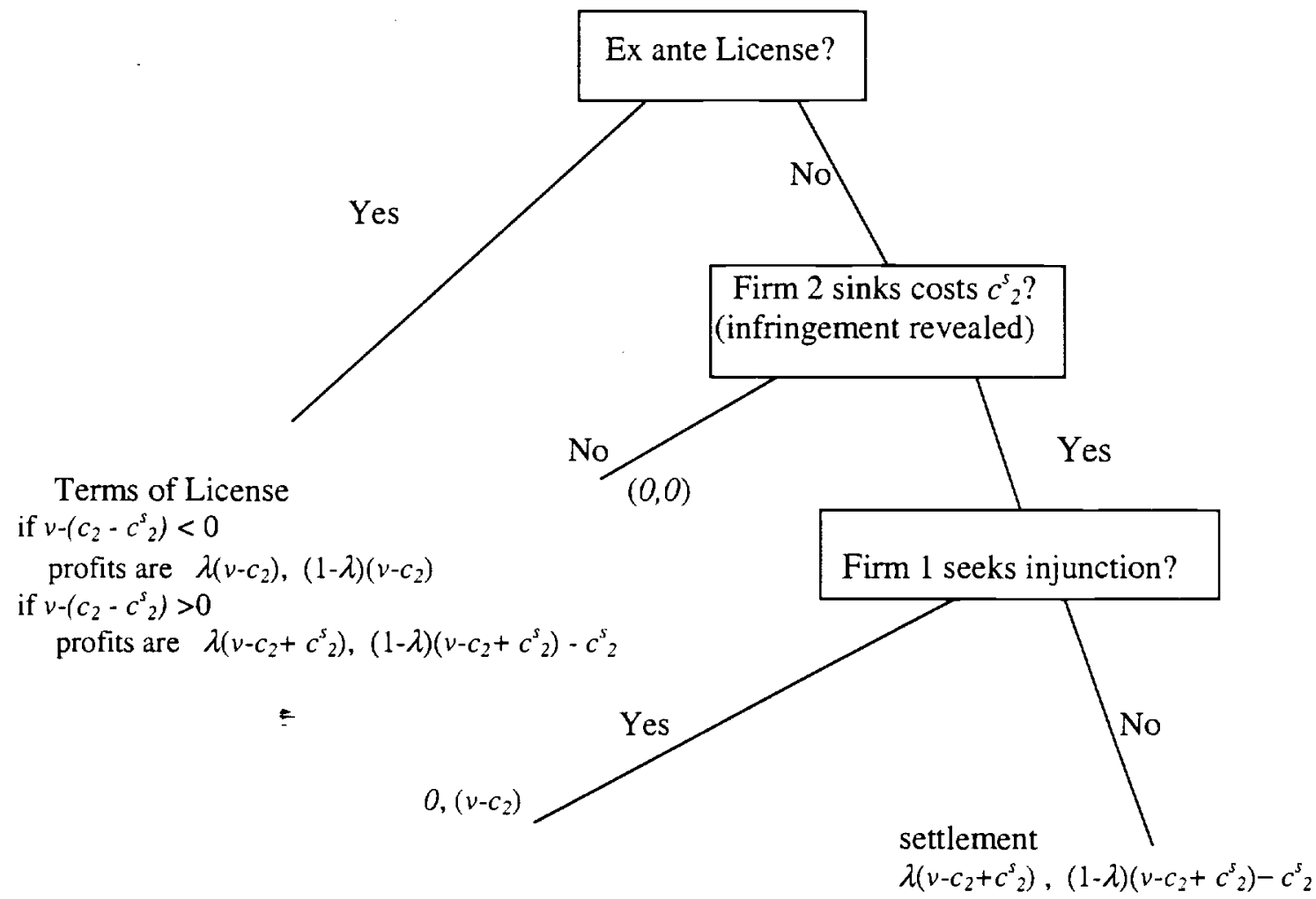

FIGURE 6. FIRM I'S PROFITS UNDER A PROPERTY RULE AS COMPARED TO A LIABLITY RULE

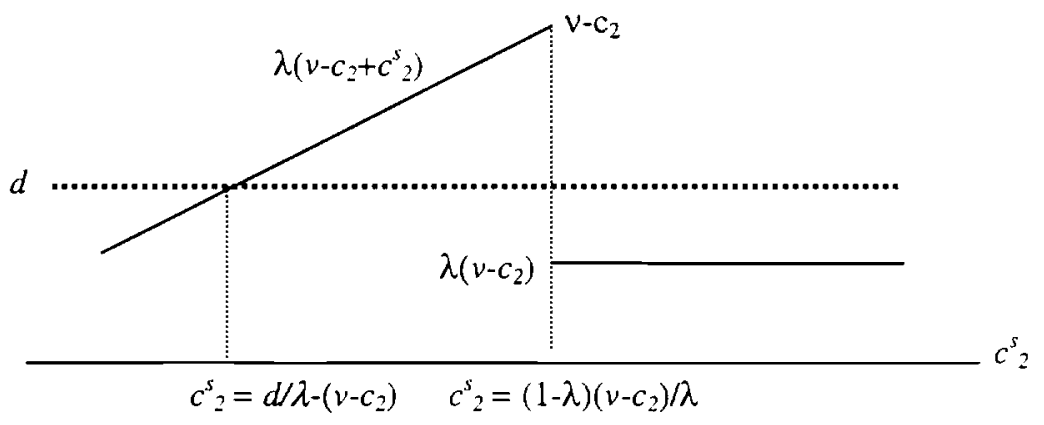


sunk, or would be ex post, after the second patent has issued and all development costs have been sunk. We explore how injunctions affect the firms' equilibrium profit. For simplicity we analyze this question assuming that firm 2 , but not the owner of the research tool, has the expertise to develop the subsequent product $\left(c_{1}>v>c_{2}\right)$.

Figure 5 shows the order of decisions. As before, we assume that firm 1 will not offer an ex ante license if it knows that, absent the ex ante license, firm 2 will embark on a program of infringement. As we shall see, firm 2's willingness to begin investing without a license depends on how much delay will occur before the injunction and settlement.

In law, the defense of laches becomes available only after unreasonable delay by the patent owner in enforcing his rights (see below). In the model, we capture this feature by assuming that the defense of laches can be invoked by firm 2 after it has sunk a portion $c_{2}^{s}$ of the total cost $c_{2}$. If the patentholder delays beyond this point, he loses his right both to enjoin and to collect damages ex post. However if he enjoins at the last possible moment, he forces a settlement in which the firms share the remaining bargaining surplus $v-\left(c_{2}-c_{2}^{s}\right)$, which is positive, since $v-c_{2}$ is positive. We first consider how the firms would like to affect $c_{2}^{s}$ after the infringing research program has begun, then consider whether firm 2 would embark on the infringing research program, and finally show how the equilibrium (ex ante) division of profit depends on $c_{2}^{s}$. The ex post perspective and ex ante perspective give different and conflicting insights.

Remark 3. Once infringement has begun, firm 1 prefers to delay injunction and settlement until all of firm 2's costs have been sunk, while firm 2 prefers that injunction and settlement occur as early as possible.

To see this, consider the right-hand side of the tree in Figure 5. With injunction and settlement when $c_{2}^{s}$ has been sunk, the profits of firms 1 and 2 are $\lambda\left(v-c_{2}+c_{2}^{s}\right)$ and $\left(v-c_{2}\right)-\lambda\left(v-c_{2}+c_{2}^{s}\right)$. The remark follows because firm 2's profit is decreasing in $c_{2}^{s}$ and firm 1's profit is increasing in $c_{2}^{s}$.

However, Remark 3 is not the right analysis from an ex ante point of view. Instead, 
Remark 4. If $c_{2}^{s}$ is sufficiently high, an infringing research program will never begin, and this reduces firm 1's profit from an ex ante point of view. Thus firm 1 can benefit by being constrained by the doctrine of laches.

Figure 6 depicts firm 1's equilibrium profit in the injunction regime as a function of the costs $c_{2}^{s}$ that firm 2 must sink before the injunction. At each $c_{2}^{s}<\left(v-c_{2}\right)(1-\lambda) / \lambda$, the patentholder's profit is $\lambda\left(v-c_{2}+c_{2}^{s}\right)$, because the remaining bargaining surplus to split is $\left(v-c_{2}+c_{2}^{s}\right) \geq 0$. However profit falls at $c_{2}^{s}=\left(v-c_{2}\right)(1-\lambda) / \lambda$. Any higher $c_{2}^{s}$ will deter investment, since firm 2's anticipated profit, $(1-\lambda)\left(v-c_{2}+c_{2}^{s}\right)-c_{2}^{s}$, is negative. Anticipating this, firm 2 has a credible incentive not to embark on an infringing investment program, which forces an ex ante agreement in which the bargaining surplus is $v-c_{2}$. That is, the patentholder is forced into a negotiation before firm 2 has sunk any costs, and this reduces his profit.

The relationship between the patentholder's profit and the severity of laches is summarized by the following proposition and Figure 6 .

Proposition 4.1. Under a property rule, the patentholder's profit increases with $c_{2}^{s}$ on the domain $\left(0,\left(v-c_{2}\right)(1-\lambda) / \lambda\right)$, has maximal value of $v-c_{2}$ at $c_{2}^{s}=\left(v-c_{2}\right)(1-\lambda) / \lambda$, and is smaller for $c_{2}^{s}>\left(v-c_{2}\right)(1-\lambda) / \lambda$ than for any $c_{2}^{s} \in\left(0,\left(v-c_{2}\right)(1-\lambda) / \lambda\right)$.

In the next proposition we compare the first patentholder's profit under a property rule with the right to injunctions after sunk $\operatorname{cost} c_{2}^{s}$ and a liability rule with damages $d$. The comparison can be seen in Figure 6 .

Proposition 4.2. Suppose that under the liability rule, damages satisfy $d<\left(v-c_{2}\right)$. Let $c_{2}^{s}$ represent the amount of delay that is allowed before the defense of laches can be invoked under a property rule. Then if $c_{2}^{s} \in\left(\frac{d}{\lambda}-c_{2}\left(v-c_{2}\right), \frac{(1-\lambda)}{\lambda}\left(v-c_{2}\right)\right)$, the patentholder earns more profit under the property rule with injunctions than under the liability rule with damages. 
Corollary 4.3. Under the property rule with injunctions, if $c_{2}^{s}=(1-\lambda)\left(v-c_{2}\right) / \lambda$, then the tool owner obtains the full surplus $v-c_{2}$.

The previous proposition and corollary explain how the allowable delay under laches should be chosen in order to guarantee that the research tool owner appropriates the full surplus. In practice, the allowable delay is constrained both by how long it takes to discover infringement (which, according to our interviews, may vary across industries) and on how much additional delay the court allows under the doctrine of laches. In biotechnology, the owner of a research tool typically learns about infringement when the infringer conducts field trials (which typically begin about halfway in the development process). This sets a lower bound to the costs that the infringer has sunk before being enjoined from continuing.

To invoke the defense of laches, a defendant must show that the patentee unreasonably delayed enforcing his property right and that this caused him injury (Columbia Broadcasting System, Inc. v. Zenith Radio Corp., 391 F.Supp. 780, 1975). In practice, the patentee has considerable latitude. However, the defense of laches is more likely to be granted by the courts if the infringer made significant investments during the period of delay. ${ }^{9}$ Moreover, in a series of recent cases, the courts have held that a delay of six years triggers a rebuttable presumption of laches, and shifts the burden of proof to the patentee to show that the defense of laches does not apply. ${ }^{10}$ In addition to laches, an infringer may invoke the related defense of estoppel. Estoppel can be invoked if the patent owner made representations by statements or conduct which implied that the patent would not be enforced, and if the defendant relied upon them and suffered injury as a result. ${ }^{11}$ Unlike laches, a defense of estoppel does not require unreasonable delay by the patent owner, and can be invoked at any time.

\footnotetext{
${ }^{9}$ Rome Grader \& Machinery Corp. v. J.D. Adams Mfg. Co., 135 F.2d 617, 1947; Whitman v. Walt Disney Productions, Inc., 148 F.Supp.37, 1957; Siemens Aktien-gesellschaft v. Beltone Electronics Corp., 381 F.Supp. 57, 1974.

${ }^{10}$ Jensen v Western Irr. and Mfg., Inc., C.A. Or. 1980, 650 F.2d 165; Lemelson v Carolina Enterprises, Inc. D.C. N.Y. 1982, 541 F.Supp. 645; Advanced Cardiovascular Systems, Inc. v Scimed Life Systems, Inc., C.A. Fed. (Alinn.) 1993, 988 F.2d 1157.

${ }^{11}$ See Studiengesellschaft Kohle mbH v Eastman Kodak Co, C.A.Tex. 1980, 616 F2d 1315. For more extensive references to the case law on laches and estoppel, see USCA (1984), Sec.282 and 286.
} 


\section{Patent Breadth and Alternative Research Tools}

Our analysis so far has assumed that the research tool is the only vehicle for achieving the later product. For some research tools, such as a genetic sequence required to develop a medical therapy, this is so. For others, such as methods for inserting foreign genetic material into cells, there may exist nonproprietary substitutes. The threat points for ex ante licensing are now established by the option to use or develop a competing tool. We shall assume that the cost of developing or using the next best research tool is $\sigma$, and that the magnitude of $\sigma$ is determined by the breadth of the patent on the research tool. We now show that our main conclusions also apply in this more general model. To do this we must reinterpret damages under the liability rule.

Firm 2 faces the choice of whether to obtain an ex ante license, and if not, then whether to infringe by using the research tool or to use the nonproprietary alternative. If he uses the alternative technology, he must pay a real cost of $\sigma$, and if he uses the patented research tool without an ex ante license, he must pay infringement damages ex post. The less costly of these determines the threat point for the ex ante agreement.

Case 1 in Table 2 describes the case where the owner of the research tool does not have a capability to invest in the product. The other cases, which depend on both firms' costs of developing the production, $c_{1}, c_{2}$, as well as the value $v$, are also summarized in the table. In Case 2 , the second product is sufficiently valuable $(v$ is sufficiently high relative to the costs) that both firms would race. If firm 2's strategy in the race is to infringe the first patent, it must pay damages $d$ if successful, so the expected damages are $d / 2$. If firm 2's strategy is to use the nonproprietary alternative at cost $\sigma$, then it pays no damages ex post. Thus, firm 2 will infringe the proprietary technology in a race if and only if $d<2 \sigma$. The two firms' expected profits in the race are written as the "threat points" for Case 2.

In Case 3, the value $v$ is lower relative to costs than in Case 2, and there is only room for one firm in the race. Firm 1 would invest if $v \geq c_{1}$ and firm 2 would invest if 


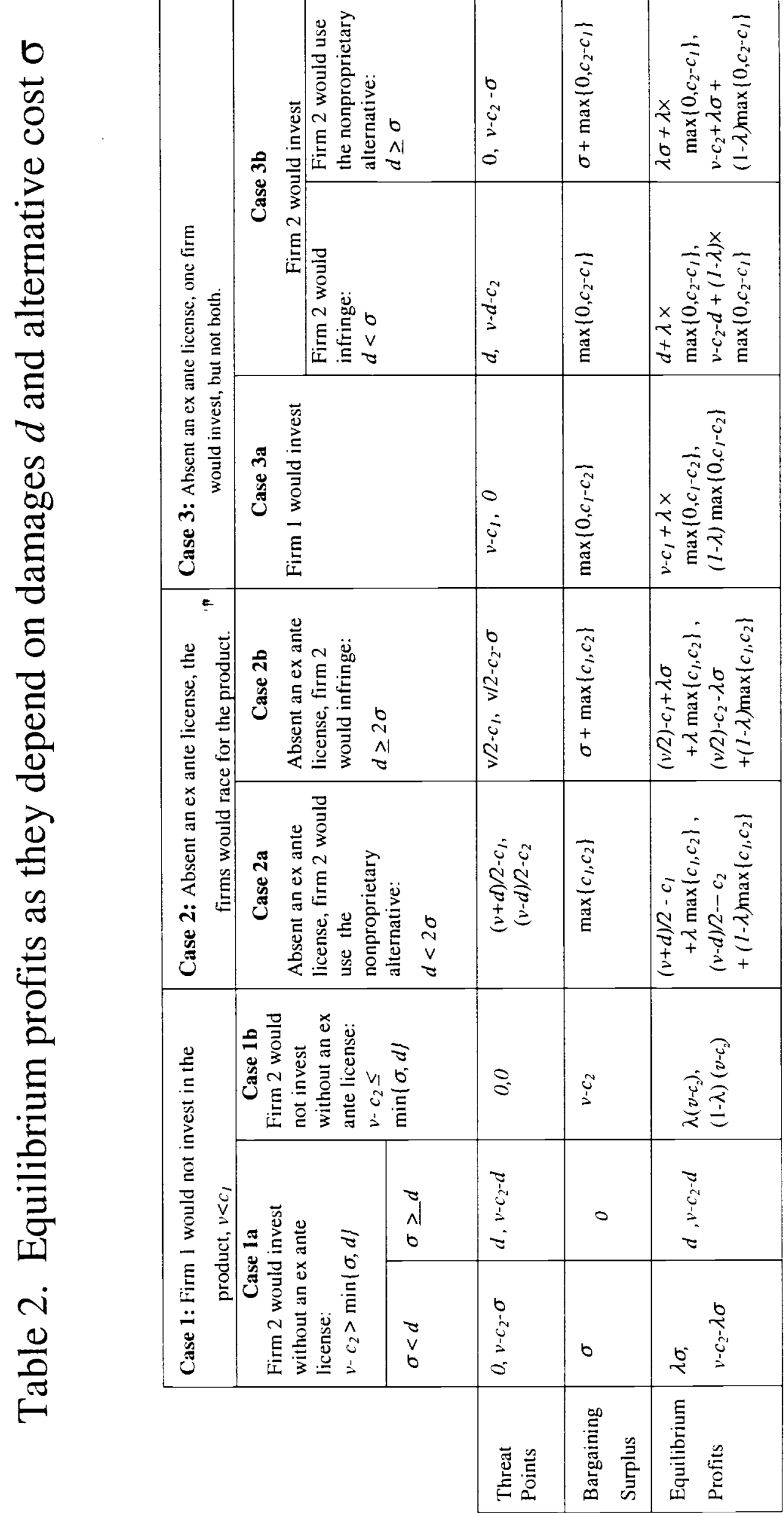


$v \geq c_{2}+\min \{\sigma, d\}$. In Case 3, either firm would be willing to invest, assuming that the other did not. There are two equilibria, absent an ex ante agreement, only one of which is efficient.

The following lemma summarizes what we learn from Table 2. The important implication is summarized in the proposition, namely that the existence of a nonproprietary alternative undermines the first firm's profit.

Lemma 5.1. Suppose that firm 1 has a patented research tool, and a nonproprietary substitute is available at cost $\sigma$. One of these tools is required to develop a new product of value $v$, and $c_{1}>v>c_{2}$. Then under a liability rule,

(i) If $\min \{d, \sigma)>v-c_{2}$, then equilibrium profits are $\left[\lambda\left(v-c_{2}\right),(1-\lambda)\left(v-c_{2}\right)\right]$.

(ii) If $\min \{d, \sigma) \leq v-c_{2}$, then equilibrium profits are

$\left[d, v-c_{2}-d\right]$ if $d \leq \sigma$;

$\left[\lambda \sigma, v-c_{2}-\lambda \sigma\right]$ if $s>\sigma$.

Proposition 5.2. Suppose that firm 1 has a patented research tool, and a nonproprietary substitute is available at cost $\sigma$. Suppose that one of these tools must be used as an input to develop a new product of value $v$, and $c_{1}>v>c_{2}$. Then, under a liability rule with damages $d$, firm 1 's profit is increasing (nondecreasing) in $\sigma$. Given $\sigma$, the damages $d$ that maximize firm 1's profit are $d=\min \left\{v-c_{2}, \sigma\right\}$.

The availability of a nonproprietary substitute changes the interpretation of both legal doctrines of damages. For the reasonable royalty doctrine, the circularity identified in Section 3 persists. Profit, hence "lost" profit, is lower when a substitute is available because the first innovator's ex ante bargaining power is lower, reducing his licensing profit in equilibrium.

By Proposition 5.2, it is impossible to have $d>\sigma$ under the reasonable royalty doctrine of damages. If $d>\sigma$, then firm 1's profit in equilibrium is only $\lambda \sigma$, which is less than $d$, a contradiction. In addition $d>v-c_{2}$ is impossible. If $d>v-c_{2}$, firm 1's profit is $\lambda\left(v-c_{2}\right)$, which is less than $d$, a contradiction. We have 
Remark 5. When there is a nonproprietary alternative to the patented research tool, the only damages $d$ that are consistent with the reasonable royalty doctrine of damages satisfy $\lambda\left(v-c_{2}\right)<d \leq \min \left\{\sigma, v-c_{2}\right\}$. The only damages $d$ that are consistent with the unjust enrichment doctrine are $d=\min \left\{\sigma, v-c_{2}\right\}$.

Thus the largest damages available under either doctrine are $\min \left\{\sigma, v-c_{2}\right\}$, and damages can be lower under the reasonable royalty doctrine. At lower damages, the owner of the research tool cannot appropriate the full surplus. Then, as in the previous sections, incentives can be imrpvoed by a property rule with injunctions, or the unjust enrichment theory under liability. 


\section{References}

[1] Aggarwal, Rajesh, (1988) "Optimal Damage awards in Cases of Patent Infringement", mimeograph, Amos Tuck School, Dartmouth College

[2] Conley, D. (1987), 'Economic Approach to Patent Damages,' 15 American Intellectual Property Law Association Quarterly, 354-380.

[3] Eisenberg, Rebecca (1989), 'Patents and the Progress of Science: Exclusive Rights and Experimental Use', 56 University of Chicago Law Review, 1017-1055.

[4] Green, Jerry and Suzanne Scotchmer (1995), 'On the Division of Profit in Sequential Innovation', The Rand Journal of Economics 26 (Spring), 20-33.

[5] Heller, Michael A. and R. S. Eisenberg (1998), 'Can Patents Deter Innovation? The Anticommons in Biomedical Research', Science 280, 698-701..

[6] Lanjouw, Jea⿳亠二口犬 and Joshua Lerner (1996), "Preliminary Injunctive Relief: Theory and Evidence from Patent Litigation," National Bureau of Economic Research Working Paper No. 5689

[7] Merges, R.P. (1994), 'Of Property Rules, Coase, and Intellectual Property', 2655 Columbia Law Review, 2661-2778.

[8] Merges, R.P. (1996), 'Contracting into Liability Rules: Intellectual Property Rights and Collective Rights Organizations', 84 UCLA Law Review, 1293-1393.

[9] Scotchmer, Suzanne (1991), 'Standing on the Shoulders of Giants:Cumulative Research and the Patent Law', Journal of Economic Perspectives, Symposium on Intellectual Property Law.

[10] Scotchmer, Suzanne (1996) "Protecting Early Innovators: Should SecondGeneration Products be Patentable?", The Rand Journal of Economics 27, 322331.

[11] United States Code Annotated, Title 35: Patents (1984; updated 1998). St. Paul, Minn: West Group. 


\section{Annex: Interview List}

John Bedbrook, Senior Vice President, DNA Plant Technology (Oakland, Ca.)

Steve Briggs, Vice President, Novartis (San Diego, Ca.)

Jerry Caulder, Executive Chairman and CEO, Xyris Corp. (San Diego, Ca.)

Arthur J. Chatroo, Director of Legal Affairs, Mycogen (San Diego, Ca.)

Dan Hunt, Senior Counsel and Head of Licensing, Chiron (Emeryville, Ca.)

Nancy Koch, Patent Litigator, Chiron (Emeryville, Ca.)

Victor Knauf, Vice President of Research, Calgene (Davis, Ca.)

Peggy Lemaux, Dept.of Plant and Microbial Biology, UC Berkeley, formerly at deKalb

Edward Penhoet, former CEO and founder, Chiron (Emeryville, Ca.)

John M. Sanders, Patent and Trademark Counsel, Mycogen (San Diego, CA.)

Carl Schwedler, Intellectual Property Counsel, Calgene (Davis, CA.) 